\title{
Intracranial Subdural Hematoma Post-Spinal Anesthesia: Report of Two Cases and Review of 33 Cases in the Literature
}

\author{
Jane Auxiliadora Amorim, TSA ${ }^{1}$, Diana Souza Canuto dos Anjos Remígio 2 , Otávio Damázio Filho, TSA ${ }^{3}$, \\ Marcos Aureliano Guerra de Barros ${ }^{4}$, Valentina Nicole Carvalho ${ }^{5}$, Marcelo Moraes Valença 6
}

Summary: Amorim JA, Remígio DSCA, Damázio Filho O, Barros MAG, Carvalho VN, Valença MM - Intracranial Subdural Hematoma Post-Spinal Anesthesia: Report of Two Cases and Review of 33 Cases in the Literature.

Background and objectives: Intracranial subdural hematoma is a rare complication of spinal anesthesia. We report two cases of women who developed chronic subdural hematoma post-spinal anesthesia diagnosed after prolonged clinical evolution of post-dural puncture headache (PDPH) and we analyze other 33 cases found on literature review.

Case reports: In 35 patients (ages 20-88 years, 19 males), 14 were older than 60 years (40\%), of which 12 (86\%) were males. The relationship is inverted in the group of younger patients (<60 years), in which we observed twice as many women (14:7). Two peaks of higher incidence were observed: $30-39$ years $(31 \%)$ and $60-69$ years (29\%). The length of time from the beginning of symptoms until diagnosis ranged from 4 hours to 29 weeks. Headache was the main complaint in 26/35 (74.3\%) patients; changes in the level of consciousness in 14/35 (40.0\%); vomiting in 11/35 $(31,4 \%)$; hemiplegia or hemiparesis in 8/35 (22.9\%); diplopia or VI nerve paresis in 5/35 (14.3\%); and language disorders in 4/35 (11.4\%). Contributing factors included: pregnancy, multiple punctures, use of anticoagulants, intracranial vascular abnormalities, and brain atrophy. In 15 cases, a contributing factor was not mentioned. Four out of 35 patients (11.4\%) remained with neurologic sequelae, and 4/35 (11.4\%) died.

Conclusions: The presence of any of the signs or symptoms mentioned above should alert for the possibility of an intracranial subdural hematoma as a complication of puncture of the dura mater, especially in those patients with PDPH for more than one week, at which time investigation by neuroimaging is necessary.

Keywords: ANESTHETIC TECHNIQUES, Regional, spinal anesthesia; COMPLICATIONS: post-dural puncture headache, subdural hematoma.

[Rev Bras Anestesiol 2010;60(6): 620-629] OElsevier Editora Ltda.

\section{INTRODUCTION}

Spinal anesthesia is routinely used in anesthesia. The incidence of rare, but severe, complications is approximately $0.05 \% 1,2$. After puncture of the dura mater, intentional or accidental, the risk of developing an intracranial subdural hematoma exists, a rare and potentially fatal complication that might be due to intracranial hypotension syndrome ${ }^{3}$. In this study, two cases of postspinal anesthesia chronic subdural hematoma diagnosed after

Received from the Centro de Ensino e Treinamento em Anestesiologia of Hospitais da Restauração (HR), Getúlio Vargas (HGV), e Oswaldo Cruz (HOC), Recife-PE, Brazil.

1. Anesthesiologist, Master's Degree in Neurosciences from Universidade Federal de Pernambuco (UFPE), Coresponsible for the CET/SBA HR, HGV e HOC), Recife-PE

2. R3 of CET/SBA HR,HGV, HOC

3. Anesthesiologist, Responsible for the CET/SBA HR, HGV e HOC

4. Anesthesiologist of HGV, Recife-PE

5. Neurologist, PhD from UFPE

6. Neurosurgery Professor, FMRP-USP, Associate Neurology and Neurosurgery Professor, Neuropsychiatry Department of UFPE

Submitted on April 10, 2010.

Approved on June 4, 2010.

Correspondence to:

Dra. Jane A. Amorim

Rua Conselheiro Nabuco, 151/1.302

Casa Amarela

52070-010 - Recife, PE

E-mail: janemarcos22@superig.com.br prolonged clinical evolution of post-dural puncture headache (PHPH) are reported. We undertook a review of the literature, finding 33 other cases of patients with intracranial subdural hematoma complicating spinal anesthesia.

\section{CASE REPORTS AND REVIEW OF THE LITERATURE Case 1}

This is 39 years old female, ASA I, with history of cesarean section under general anesthesia, due to failure of neuroaxis block, 10 years before the current admission. She denied history of headache, trauma, neurological disease, and coagulopathy. Routine preoperative exams were within normal limits. She underwent spinal anesthesia in the sitting position in the $L_{3}-L_{4}$ space with a $27 \mathrm{G}$ Quincke needle and $15 \mathrm{mg}$ of hyperbaric bupivacaine for surgical hysteroscopy. Since a complete failure of the sensorial and motor blockade was observed, a second puncture was performed with similar needle and anesthetic solution that was successful. Eighteen hours later, she developed severe postural headache in the frontotemporal region, without associated neurological signs and symptoms. Post-dural puncture headache was diagnosed and it was decided to treatment her conservatively with analgesics, intravenous hydration, and bed rest. After 24 hours, she was discharged from the hospital with partial relief of symptoms. Twenty days after the puncture, the patient remained with moderate 
daily headache, but without the postural component. During this period, she went to her surgeon who advised her to continue taking the analgesics and to go to a pain specialist if her pain did not improve. After 42 days, the headache became unbearable, and it was accompanied by nausea and vomiting. She went to the emergency room and an MRI of the head showed the presence of an intracranial subdural hematoma in the left side with a shift of the intracranial midline structures (Figure 1). Subsequently, the patient underwent trepanning with removal of the hematoma. Her symptoms resolved and the patient did not develop any sequelae.

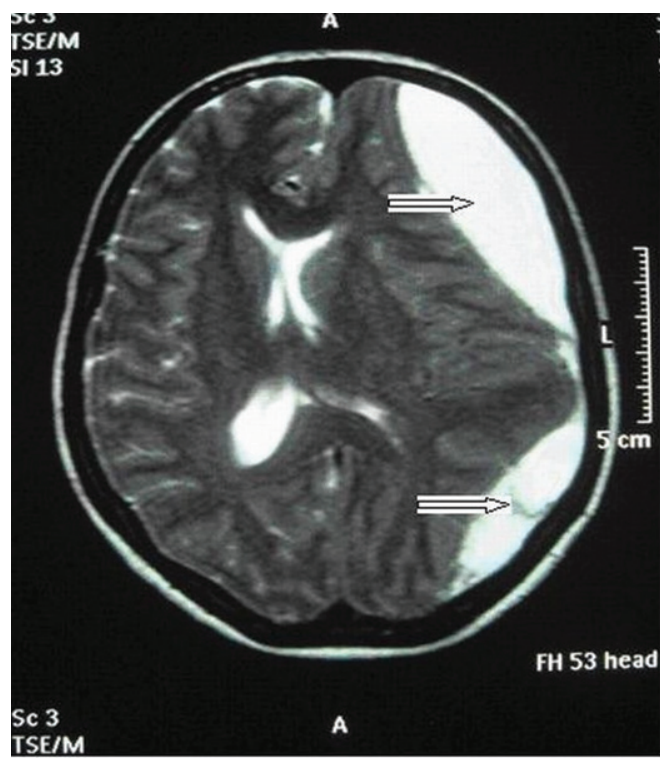

Figure 1 - MRI of the Head 42 Days After Spinal Anesthesia Showing a Chronic Subdural Hematoma on the Left with a Shift of Structures in the Midline.

\section{Case 2}

This is a 32 years old female, ASA I, pregnant II/para I, who underwent spinal anesthesia in the sitting position for cesarean section. After the fourth attempt, the L3-L4 space was punctured with a 27G Quincke needle and $13 \mathrm{mg}$ of hyperbaric bupivacaine associated with morphine was successfully injected. She had a history of a surgical delivery under neuroaxis block without intercurrences. Her current pregnancy was normal and she did not have a history of headache, trauma, neurological disease, or coagulopathy. Complete blood count and coagulogram were within normal limits. Twelve hours after the anesthesia, the patient developed severe postural headache bilaterally in the frontal region. Post-dural puncture headache was diagnosed and it was decided to treat her clinically. She was discharged from the hospital with partial relief of her symptoms. Postural headache persisted for 27 days when it changed from postural to non-postural headache. During this period, the patient went to the emergency room twice, being treated with analgesics. After 40 days, the headache became unbearable. An MRI of the head showed an image suggestive of chronic subdural hematoma in the frontoparietal region, bilaterally (Figure 2 ) that exerted mild compression on the cerebral hemispheres. She was treated with bed rest and analgesics and follow-up appointments with a neurologist. Two control MRIs were performed and, after 50 days, complete resorption of the hematomas (Figure 3) and improvement of her symptoms was observed.

The subject was reviewed by searching the electronic data bases of PUBMED, LILACS, and SCIELO. We used a combination of the following words in our search: "intracranial subdural hematoma" and "subarachnoid OR spinal anesthesia". We selected articles published until January 2010 in Portuguese, English, and Spanish, and we found 33 cases of patients with intracranial subdural hematoma after dura mater/ arachnoid puncture for spinal anesthesia. Table I shows the

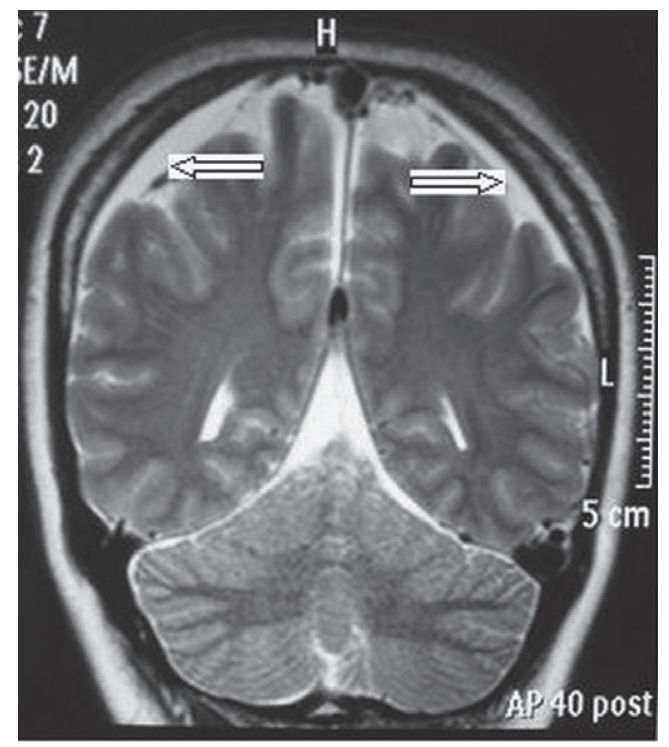

Figure 2 - MRI of the Head 40 Days After Spinal Anesthesia Showing an Image Suggestive of a Chronic Subdural Hematoma in the Frontoparietal Region Bilaterally.

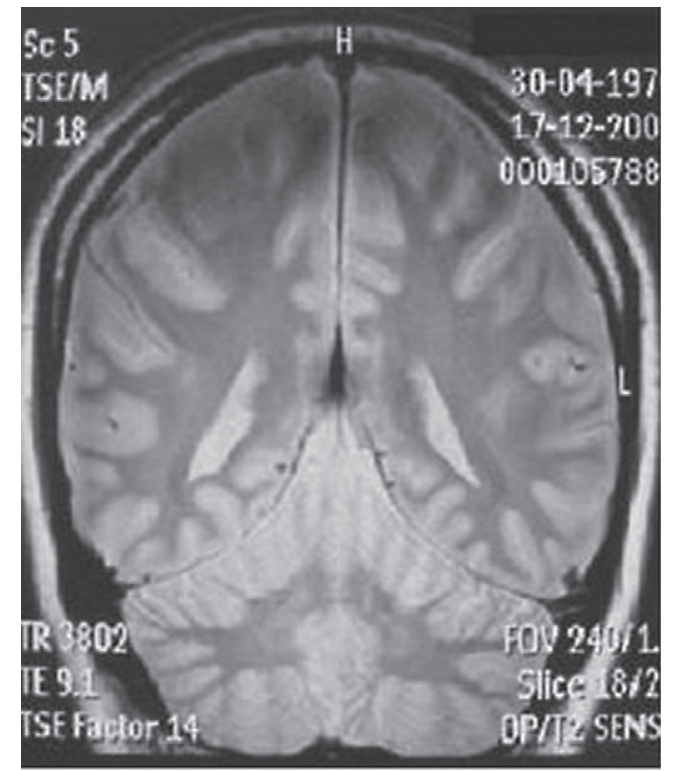

Figure 3 - MRI of the Head Showing Reabsorption of the Hematomas 52 Days After the Diagnosis. 
Table I - Reported Cases of Intracranial Subdural Hematoma Post-spinal Anesthesia

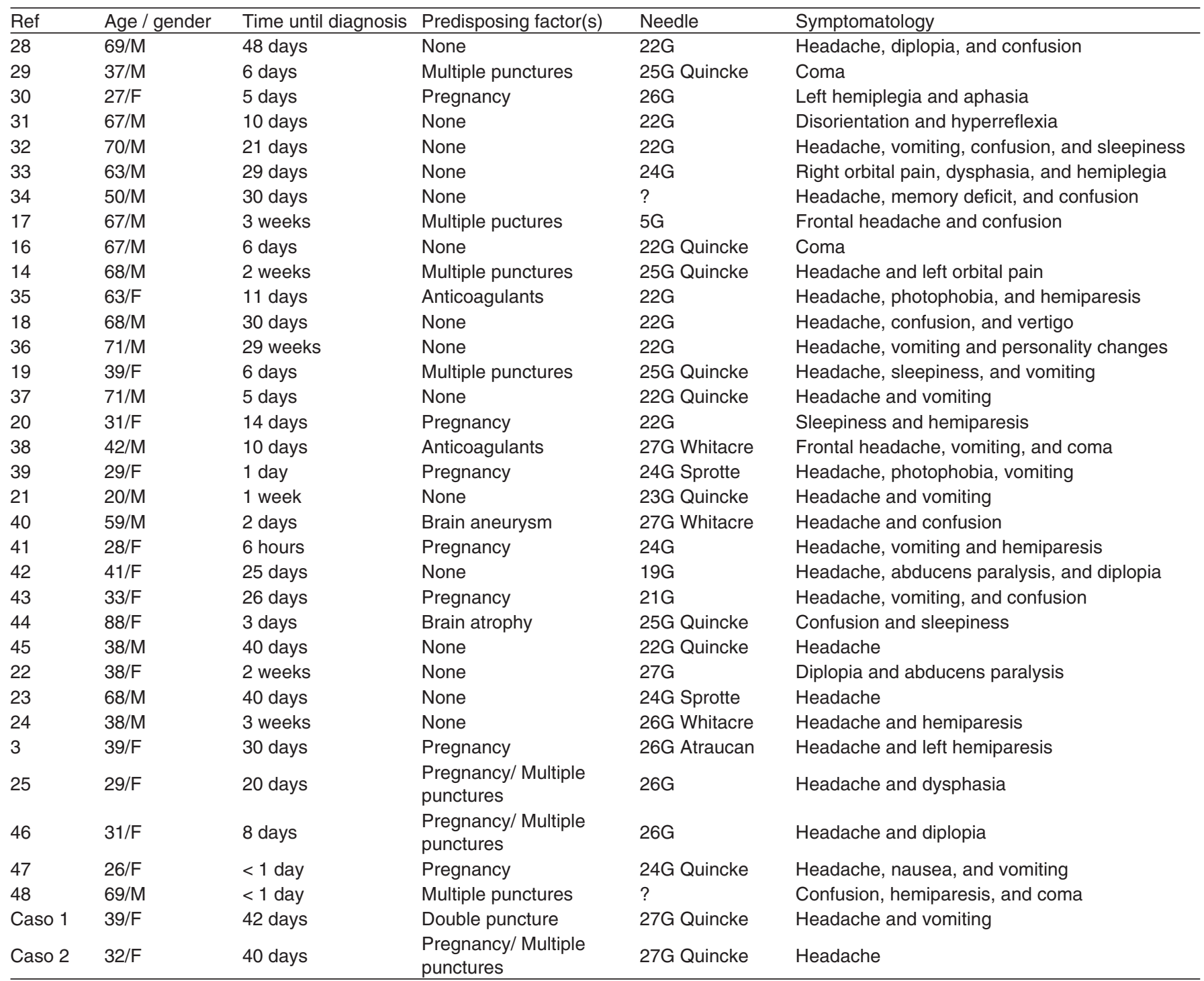

Ref = reference; $M=$ male; $F=$ female.

demographic and clinical data of 35 patients (including the two cases reported here). We obtained an informed consent of our two patients to publish their cases.

In those 35 cases, the age ranged from 20 to 88 years ( 49 \pm 18 years; median 41 years), 19 were males and 16 females. Fourteen patients (40\%) were older than 60 years and in this population of elderly individuals 12 out of 14 (86\%) were males (male:female ratio of $6: 1$ ). This gender relationship inverts in the group of younger patients (<60 years), with twice as many females $(n=14)$ than males $(n=7)$ (male:female ratio of 1:2). Two peaks of higher frequency were observed, 33-39 years and 60-69 years.

The time between the onset of the symptoms until the diagnosis ranged from 4 hours to 29 weeks ( $22 \pm 35$ days; median 14 days). Headache was the complaint of $26 / 35$ (74.3\%) patients; changes in the level of consciousness in 14/35 (40.0\%) patients; vomiting in 11/35 (31.4\%); hemiplegia or hemiparesis in $8 / 35$ (22.9\%); diplopia or VI nerve paresis in 5/35 (14.3\%); and language disorders in 4/35 (11.4\%). Contributing factors for those complications included: pregnancy, multiple punctures, use of anticoagulants, intracranial vascular abnormalities, and cerebral atrophy. No contributing factor was mentioned in 15 cases. Four out of 35 (11.4\%) patients developed neurological sequelae, and 4/35 (11.4\%) died.

\section{DISCUSSION}

Headache is the most common complication after intentional dura mater/arachnoid puncture for diagnosis, treatment, and spinal anesthesia, or accidentally during spinal anesthesia ${ }^{4}$. Postural headache is the pathognomonic characteristic of $\mathrm{PDPH}$. According to the diagnostic criteria of the International Headache Society (2004, ICHD-II) ${ }^{5}$, the pain worsens or develops within 15 minutes after the individual sits or stands up, and it improves within a similar period after the individual 
lays down. It develops within 5 days after the puncture and disappears spontaneously within 1 week or up to 48 hours after epidural blood patch. When the headache persists this causal relationship should be doubted and other cause of headache, primary or secondary, which can simulate or even coexist with this condition should be investigate.

In the present study, and in both cases, the duration of the headache for more than one week did not fulfill the diagnostic criteria of PDPH. Studies that evaluated the time course of PDPH demonstrated that in approximately $95 \%$ of the cases the symptoms subsided within 5 days ${ }^{6,7}$. In rare situations, the duration can be longer than the time established in the diagnostic criteria, since neuroimaging exams demonstrate the absence of intracranial lesions, and the cerebrospinal fluid (CSF) shows low pressure and absence of infection or bleeding ${ }^{4-7}$. In one of our studies with 640 patients with $\mathrm{PDPH}$, one of the patients remained with the postural headache for 15 days. MRI of the head did not show expanding intracranial lesions, and for remission of the pain an epidural blood patch was applied twice ${ }^{7}$.

After puncture of the dura mater/arachnoid, some factors related to the puncture technique and to the patient are associated with a higher incidence of PDPH, such as: caliber, design, and direction of the bevel of the needle ${ }^{8,9}$, female gender ${ }^{10}$, gestational state ${ }^{11}$, history of PDPH ${ }^{12}$, density of the CSF, and width and elasticity of the dura mater/arachnoid ${ }^{13}$. Some studies demonstrated that the puncture orifice can remain opened for up to 18 weeks and extravasation of CSF can reach up to 240 $\mathrm{mL}$ day $^{-1}$ in orifices of $0.6 \mathrm{~mm}$ of diameter ${ }^{14,15}$, which causes loss of the autoregulation mechanisms of intracranial pressure and justifies the prolonged evolution of the PDPH episode, generating incapacity and patient dissatisfaction with the anesthesia. Besides, persistently low CSF pressure can impose traction and rupture subdural blood vessels, leading to the formation of a hematoma between the dura mater and arachnoid ${ }^{3}$, as had been seen in both cases presented here. Also, intracranial hemorrhage secondary to the rupture of a brain aneurysm or arteriovenous malformation, although rare in the subdural location can develop due to low CSF pressure or the stress of the anesthetic surgical procedure and increase in blood pressure ${ }^{16}$. In the cases reported here, magnetic resonance angiography of brain vessels did not demonstrate the presence of aneurism or arteriovenous malformation.

Besides the prolonged evolution of PDPH, another alert sign that was not considered early in the course of both cases was the change in the postural character of the headache for non-postural, which was also observed in other cases in the literature $3,16-25,37,46$. The clinical manifestations of subdural hematoma depend on age, size, location, speed of formation of the blood collection, compression of intracranial structures, and clinical condition of the patient ${ }^{26,27}$. However, the differential diagnosis between neurological symptoms of low CSF pressure and subdural hematoma can be difficult, hindering the early diagnosis.

In chronic post-dural puncture subdural hematoma, the clinical picture is characterized by a two-phase evolution: initially, patients present postural headache associated with other neurologic, vestibular, visual, and auditory symptoms or not. Pain relief can be obtained with common clinical treatment; however, in general, symptoms persist. Unlikely what is seen in PDPH, an epidural blood patch does not improve symptoms, and it can even worsen them. On a second phase, gradual increase in headache, that is no longer related to orthostatic position, is observed and neurologic signs and symptoms can be present - and in this period they are no longer related to low CSF pressuren, but to an increase in intracranial pressure. In 3 out of the 35 cases reviewed, we only found report of headache. In 31 out of 35 cases $(89 \%)$, at least one of the following signs were present (besides headache): vomiting, diplopia, cognitive changes or changes in consciousness level, or focal neurologic signs (i.e., motor deficit or changes in language). Therefore, the presence of any of those signs or symptoms should alert the physician for the possibility of an intracranial subdural hematoma complicating the dural puncture, especially in those patients with PDPH.

Among the contributing factors in the 35 reported cases, these were mentioned in decreasing order: pregnancy, multiple punctures, use of anticoagulants, intracranial vascular abnormalities, and brain atrophy. Probably many of those factors were not systematically investigated, such as in the case of brain atrophy that is common in the elderly. However, 15 patients did not present - or it was not mentioned - any contributing factor for this complication, which is an important data. Besides, cases in which spinal anesthesia was performed with fine needles with Witacre-, Sprotte-, and Atraucan-type bevel have also been reported, which demonstrate that the use of those needles does not prevent the development of this complication. In the first case reported here, the patient presented as contributing factor a double puncture, while in the second case, pregnancy and multiple puncture attempts might have caused more than one orifice penetrating the dura mater.

In the 35 cases reported here, 27 patients required surgical drainage. Conservative treatment is indicated for small blood collections without deviation of the structures in the intracranial midline that do not cause relevant clinical repercussions, as was the case of the second patient reported here. Note that in bilateral lesions of equal volumes, a shift in intracranial midline structures is not expected. Four patients out of the 35 reviewed developed neurologic sequelae 29,30,41,48 and four died 6,28,31,38.

To conclude, PDPH is an unpleasant complication and most times causes temporary incapacitation. However, in rare situations, more severe neurologic complications can develop.

A high degree of suspicion is fundamental for the diagnosis of chronic intracranial subdural hematoma in patients that: (1) develop postural headache for more than 1 week; (2) do not improve or show worsening headache with clinical treatment or after an epidural blood patch; (3) changes in pain from postural to non-postural; or (4) develop other neurologic signs or symptoms besides the headache. When facing any of those situations, the investigation with a head CT or MRI is mandatory. Pregnant women and elderly male patients who underwent multiple punctures and/or are on anticoagulants or antiplatelet drugs seem to be more susceptible to the formation of subdural hematoma after spinal anesthesia and careful observation is recommended. 


\section{REFERÊNCIAS / REFERENCES}

01. Aromaa U, Lahdensuu M, Cozanitis DA - Severe complications associated with epidural and spinal anaesthesias in Finland 1987-1993. A study based on patient insurance claims. Acta Anaesthesiol Scand, 1997;41:445-452.

02. Auroy $\mathrm{Y}$, Narchi $\mathrm{P}$, Messiah A et al. - Serious complications related to regional anaesthesia: results of a prospective survey in France. Anesthesiology, 1997;87:479-486.

03. Zeidan A, Farhat $\mathrm{O}$, Maaliki $\mathrm{H}$ et al. - Does postdural puncture headache left untreated lead to subdural hematoma? Case report and review of the literature. Int J Obstet Anesth, 2006;15:50-58.

04. Amorim JA, Maciel CMC, Damázio Filho $O$ et al. Cefaleia pós-punção dural: fisiopatologia, diagnóstico e fatores de risco. Rev Dor, 2007;8:1014-1027.

05. International Headache Society - International Classification of Headache Disorders (ICHD-II). Second Edition. Cephalalgia, 2004; (Suppl 1):1-160.

06. Lybecker H, Djernes M, Schmidt JF - Postdural puncture headache (PDPH): onset, duration, severity, and associated symptoms. An analysis of 75 consecutive patients with PDPH. Acta Anaesthesiol Scand, 1995;39:605-612.

07. Amorim JA, Valença MM - Cefaleia pós-punção dural: os novos critérios diagnósticos da ICHD II - 2004 devem ser modificados. Migrâneas Cefaléias 2008;11: 233-237.

08. Imbelloni LE, Sobral MGS, Carneiro ANG - Cefaleia pós-raquianestesia e o desenho das agulhas. Experiência com 5050 Casos. Rev Bras Anestesiol, 2001:51:43-52.

09. Valença MM, Amorim JA, Barros MVG -. Risk factors for postdural puncture headache: experience with spinal anesthesia. Cephalalgia 2007:27:716-717.

10. Wu CL, Rowlingson AJ, Cohen SR et al. - Gender and postdural puncture headache. Anesthesiology, 2006;105:613-618.

11. Choi PT, Galinski SE, Takeuchi L et al. - PDPH is a common complication of neuraxial blockade in parturients: a meta-analysis of obstetrical studies. Can J Anaesth, 2003;50:460-469.

12. Amorim JA, Valença MM - Postdural puncture headache is a risk factor for new postdural puncture headache. Cephalalgia, 2008;28:5-8.

13. Kempen PM, Mocek CK - Bevel direction, dura geometry, and hole size in membrane puncture: laboratory report. Reg Anesth, 1997:22:267-272.
14. Macon ME, Armstrong L, Brown EM - Subdural hematoma following spinal anesthesia. Anesthesiology, 1990;72:380-381.

15. Eerola M, Kaukinen L, Kaukinen S - Fatal brain lesion following spinal anaesthesia. Acta Anaesth Scand, 1981;25:115-116.

16. Beal JL, Royer JM, Freysz $M$ et al. - Hematome sous-dural aigu intracranien d'origine arterielle apres rachianesthesie. Ann $\mathrm{Fr}$ Anesth Reanim, 1989; 8:143-145.

17. Blake DW, Donnan G, Jensen D - Intracranial subdural haematoma after spinal anaesthesia. Anaesth Intensive Care, 1987;15:341342.

18. Van de Kelft E, De la Porte C, Meese G et al. - Intracranial subdural hematoma after spinal anesthesia. Acta Anaesthesiol Belg, 1991; 42:177-180

19. Bisinoto FMB, Martins Sobrinho J, Augusto CM et al. Hematoma subdural encefálico após anestesia subaracnoidea. Rev Bras Anestesiol, 1993;43:199-200.

20. Akpek EA, Karaaslan D, Erol E et al. - Chronic subdural haematoma following caesarean section under spinal anaesthesia. Anaesth Intensive Care, 1999;27:206-208.

21. Acharya R, Chhabra SS, Ratra M et al. - Cranial subdural haematoma after spinal anaesthesia. Br J Anaesth, 2001;86:893-895.

22. Slowinski J, Szydlik W, Sanetra A et al. - Bilateral chronic subdural hematomas with neurologic symptoms complicating spinal anesthesia. Reg Anesth Pain Med, 2003;28:347-350.

23. Landman DO, Jerome MD, Glass MB - Subdural hematoma after atraumatic spinal anesthesia. J Clin Anesth, 2005;17:379-381.

24. Acharya R - Chronic subdural haematoma complicating spinal anaesthesia. Neurol Sci, 2005;25:348-350.

25. Verdú, MT, Martínez-Lage JF, Alonso B et al. - Non-surgical management of intracranial subdural hematoma complicating spinal anesthesia. Neurocirugia (Astur), 2007;18:40-43.

26. Pereira CU, Andrade Filho AS - Hematoma Subdural Crônico no Idoso. em: Pereira CU, Andrade Filho AS - Neurogeriatria. Rio de Janeiro, Revinter, 2000;346-349.

27. Mellergard $\mathrm{P}$, Wisten $\mathrm{O}-$ Operations and re-operations for chronic subdural haematomas during a 25-year period in a well defined population. Acta Neurochir (Wien), 1996;138:708-713.

28. Welch $\mathrm{K}$ - Subdural hematoma following spinal anesthesia. Arch Surg 1959; 79:49-51.

29. Pavlin DJ, McDonald JS, Child B et al. - Acute subdural hematoma an unusual sequela to lumbar puncture. Anesthesiology, 1979;51:338-340.

30. Mantia AM - Clinical report of the occurrence of an intracerebral hemorrhage following post-lumbar puncture headache. Anesthesiology, 1998; 55:684-685.

31. Newrick P, Read D - Subdural haematoma as a complication of spinal anaesthetic. Br Med J, 1982;285:341-342.

32. Rudehill A, Gordon E, Rahn T - Subdural haematoma. A rare but lifethreatening complication after spinal anaesthesia. Acta Anaesthesiol Scand, 1983;27:376-377.

33. Jonsson LO, Einarsson P, Olsson GL - Subdural haematoma and spinal anaesthesia. A case report and an incidence study. Anaesthesia, 1983; 8:144-146.

34. Giamundo A, Benvenuti D, Lavano A et al. - Chronic subdural haematoma after spinal anaesthesia. Case report. J Neurosurg Sci, 1985;29:153-155

35. Ortiz M, Aliaga L, Baturell C et al. - Intracranial subdural haematoma - a rare complication after spinal anaesthesia. Eur J Anaesthesiol, 1991;8:245-248.

36. Baldwin LN, Galizia EJ - Bilateral subdural haematomas: a rare diagnostic dilemma following spinal anaesthesia. Anaesth Intensive Care, 1993;21:120-121.

37. Bjarnhall M, Ekseth $\mathrm{K}$, Bostrom S et al. - Intracranial subdural haematoma: a rare complication following spinal anaesthesia. Acta Anaesthesiol Scand, 1996;40:1249-1251.

38. Cantais E, Behnamou D, Petit D et al. - Acute subdural hematoma following spinal anesthesia with a very small spinal needle. Anesthesiology, 2000;93:1354-1356.

39. Eggert SM, Eggers KA - Subarachnoid haemorrhage following spinal anaesthesia in an obstetric patient. Br J Anaesth, 2001;86:442-444. 
40. Wells JB, Sampson IH - Subarachnoid hemorrhage presenting as post-dural puncture headache: a case report. Mt Sinai $\mathrm{J}$ Med 2002;69:109-110.

41. Sharma K - Intracerebral hemorrhage after spinal anesthesia. J Neurosurg Anesthesiol, 2002;14:234-237.

42. Alilou M, Halelfadl S, Caidi A et al. - Une nouvelle observation d'hematome sous-dural chronique intracranien au decours d'une rachianesthesie. Ann Fr Anesth Reanim 2003; 22:560-561.

43. Miyazaki S, Fukushima $\mathrm{H}$, Kamata $\mathrm{K}$ et al. - Chronic subdural hematoma after lumbar-subarachnoid analgesia for a cesarean section. Surg Neurol, 1983;19:459-460.

44. Tan ST, Hung CT - Acute-on-chronic subdural haematoma: a rare complication after spinal anaesthesia. Hong Kong Med J, 2003;9:384-386.

45. Kelsaka E, Sarihasan B, Baris S et al. - Subdural hematoma as a late complication of spinal anesthesia. J Neurosurg Anesthesiol, 2003;15:47-49.

46. Ramos-Aparici R, Segura-Pastor D, Edo-Cebollada L et al. - Acute subdural hematoma after spinal anesthesia in an obstetric patient. J Clin Anesth, 2008;20:376-378.

47. Dawley B, Hendrix A - Intracranial subdural hematoma after spinal anesthesia in a parturient. Obstet Gynecol 2009;113:570-573.

48. Rocchi R, Lombardi EC, Marradi El et al. - Intracranial and intraspinal hemorrhage following spinal anesthesia. Neurol Sci, 2009;30:393-396.

Resumen: Amorim JA, Remígio DSCA, Damázio Filho O, Barros MAG, Carvalho VN, Valença MM - Hematoma Subdural Intracraneal Postanestesia Subaracnoidea: Relato de dos Casos y Revisión de 33 Casos de la Literatura.

Justificativa y objetivos: El hematoma subdural intracraneal es una complicación rara postanestesia subaracnoidea. Relatamos aquí dos casos de mujeres que desarrollaron hematoma subdural crónico postanestesia Subaracnoidea, diagnosticados posteriormente a la evolución clínica prolongada de cefalea postpunción dural (CPPD), y analizamos otros 33 casos encontrados en una revisión de la literatura.

Relato de los casos: En los 35 pacientes (edad entre 20 y 88 años, 19 hombres), 14 tenían más de 60 años (40\%) siendo 12 (86\%) hombres. La relación se invierte en el grupo de pacientes más jóvenes (<60 años), en donde encontramos dos veces más mujeres (14:7). En los picos de mayor incidencia se observaron: de 30 a 39 años (31\%) y de 60 a 69 años (29\%). El período de tiempo transcurrido entre el inicio de los síntomas hasta el diagnóstico varió entre 4 horas y 29 semanas. La cefalea fue relatada por $26 / 35$ (74,3\%) casos; la alteración del nivel de conciencia en 14/35 (40,0\%); vómitos en 11/35 (31,4\%); hemiplejía o hemiparesia en $8 / 35$ (22,9\%); diplopía o paresia del VI nervio craneal en 5/35 (14,3\%); y disturbio del lenguaje en $4 / 35(11,4 \%)$. Los factores contribuyentes fueron: el embarazo, múltiples punciones, uso de anticoagulantes, anormalidades vasculares intracraneales y atrofia cerebral. En 15 casos, no se citó ningún factor contribuyente. En $4 / 35(11,4 \%)$ pacientes quedaron con secuelas neurológicas y $4 / 35$ (11,4\%) fallecieron.

Conclusiones: La presencia de cualquier una de esas señales o síntomas mencionados, sirve de alerta para la posibilidad del aparecimiento del hematoma subdural intracraneal como complicación de la punción dural, principalmente en aquellos pacientes que presentaron CPPD durante más de una semana, haciéndose necesaria una investigación por neuro imagen. 